\title{
Survey and Collection of Bacterial Wilt (Ralstonia solanacearum) Isolates from Different Agro Climatic Zones of Karnataka
}

\author{
Santosh Bangi, V. Devappa* and C. G. Sangeetha \\ Department of Plant Pathology, College of Horticulture, University of Horticultural Sciences \\ Campus, GKVK Post, Bengaluru, India \\ *Corresponding author
}

\section{A B S T R A C T}

\begin{tabular}{|l|}
\hline Ke y w o r d s \\
Bacterial wilt, \\
$\begin{array}{l}\text { Diease incidence, } \\
\text { Ralstonia } \\
\text { solanacearum }\end{array}$ \\
\hline Article Info \\
\hline $\begin{array}{l}\text { Accepted: } \\
\text { 22 June } 2020 \\
\text { Available Online: } \\
\text { 10 July } 2020\end{array}$ \\
\hline
\end{tabular}

\section{Keywords}

Bacterial wilt, Diease incidence, solanacearum

\section{Introduction}

Brinjal (Solanum melongena L.) is one of the important vegetable crop, belonging to the family Solanaceae. It features virtually in all the dishes of every household in India, irrespective of food preferences, income levels or social status. As a part of the most basic or sophisticated Indian meal, brinjal is used in the preparation of a number of sumptuous dishes. Further, in recent years brinjal is being exported in the form of products like bainganbhartha, chatni, pickles etc. to Middle East countries. Brinjal is the second most important vegetable growing in India after potato. In the world, brinjal is grown in an area of about 1.86 million hectare, with production of 49.78 million tonnes with a productivity of 26.07 tonnes per hectare (Anon., 2014). In India, it is mainly grown in Odisha, Bihar, Karnataka, West Bengal, Andhra Pradesh, Telangana, Maharashtra and Uttar Pradesh.

The total area, production and productivity of brinjal crop in India is 0.922 million hectare, 13.5 million tonnes and 19.1 tonnes per hectare, respectively (Anon., 2014) and it contributes about 8.3 per cent of total Indian vegetable production. In Karnataka, it is grown in an area of 0.15 lakh hectare with a production of 4.02 lakh tonnes and 
productivity of 25.4 tonnes per hectare (Anon., 2014).Successful cultivation of brinjal crop has been hindered due to attack of many pest and devastating diseases. Among diseases, bacterial wilt caused by Ralstonia solanacearum (Smith) is a major limiting factor. It has been the most ubiquitous and serious bacterial disease throughout the tropical, sub-tropical and temperate regions of the world (Hayward, 1991).

In India, this disease is of major concern and is serious in major parts of Karnataka, Kerala, Odisha, Maharashtra, Madhya Pradesh and West Bengal (Rao et al., 1976) causing economic yield losses upto 86.14 per cent (Sabita et al., 2000).

\section{Materials and Methods}

\section{Survey}

Roving survey was conducted to know the incidence of bacterial wilt of brinjal and collection of $R$. solanacearum isolates causing bacterial wilt from different agro climatic zones of Karnataka. The plants showing typical symptoms were collected from the fields representing different agro climatic areas. Total number of plants and number of wilt affected plants were counted from randomly selected rows in the field and per cent wilt incidence was calculated.

$$
\text { Per cent disease incidence }=\frac{\text { Total number of plants wilted }}{\text { Total number of plants }} \times 100
$$

\section{Collection of sample}

After recording the observation, the wilted plants showing typical symptoms of bacterial wilt were uprooted and collected. The collected samples were labelled and packed in polythene bags and kept at $4^{\circ} \mathrm{C}$ for the purpose of isolation of the causal organism.

\section{Isolation of Ralstonia solanacearum from bacterial wilt infected plants}

Brinjal plants showing typical symptoms of bacterial wilt caused by Ralstonia solanacearum collected from different agroclimatic zones of the state were used for the isolation of the causal organism. The preliminary diagnosis of the disease was done by checking the bacterial ooze from the discolored vascular tissues of the affected plants. The bacteria was isolated from the infected plants by extracting the ooze in sterile distilled water taken in small vials followed by dilution plating on Triphenyl Tetrazolium Chloride (TTC) agar medium.

Small pieces of discolored vascular tissue measuring 4-5 $\mathrm{mm}$ in length were cut from the discolored vascular tissues of the stem. The tissue was surface sterilized by immersing bits in 1 per cent sodium hypochlorite for 30 seconds. The disinfected tissue was washed in sterile water to remove traces of sodium hypochlorite, if any. The surface sterilized bits were then suspended in ten milliliter sterile distilled water taken in a test tube for ten minutes. After the water in the test tube became turbid due to oozing of the bacterial cells from the cut ends of the diseased tissue the bacterial suspension was serially diluted in nine milliliter sterile distilled water. One hundred microliter of the diluted bacterial suspension was poured onto the surface of solidified TriphenylTetrazolium Chloride agar (TTC) medium (Kelman, 1954) in sterilized Petri plates. The bacterial suspension was spread onto the surface of TTC medium with a sterilized spreader. The inoculated plates were incubated at $28^{\circ} \mathrm{C}$ for 48 hours.

At the end of the incubation period, the plates were observed for the development of well separated irregularly shaped, fluidal, dull white colonies with slight red center typical of virulent $R$. solanacearum colonies. The 
concentration of the inoculum was adjusted to 0.3 Optical Density (OD) at $600 \mathrm{~nm}$ wave length (approximately 1.0 x $108 \mathrm{cfu} / \mathrm{ml}$ ) using spectrophotometer. The composition of the TTC agar medium used is as follows: 1.0 per cent peptone, 0.1 per cent Casein hydrolysate and 0.5 per cent Dextrose and 1.5 per cent agar in $1000 \mathrm{ml}$ of distilled water. One $\mathrm{ml}$ of 1 per cent aqueous solution of triphenyltetrazolium chloride was added to $200 \mathrm{ml}$ medium after sterilization and prior to pouring into the Petri plates.

\section{Results and Discussion}

Roving survey was conducted in different agro climatic zones of Karnataka for assessing the bacterial wilt incidence and collection of disease samples. The results of the survey were depicted in Table 1, Plate 1 and Figure 1. Based on the results of roving survey in major brinjal growing areas of Karnataka, it was evident that the incidence of Ralstonia solanacearum was highly prevalent across all brinjal growing areas. The per cent disease incidence varied significantly across all places and maximum disease incidence was recorded in Chikkaballapur (27.60\%) followed by Dharwad (22.51\%), while, the least incidence was observed in Mysuru $(4.62 \%)$ followed by Hassan $(6.37 \%)$ and Tumakuru $(7.18 \%)$.

Wherever, wilted plant was observed, there it was strongly noted that the absolute association of $R$. Solanacearum with plant which was confirmed by ooze test. The high incidence of the disease in Karnataka region indicates that it is a recurrent problem in the brinjal growing areas.

This may be due to susceptibility of the cultivars or favourable environmental conditions like temperature and continuous rainfall experienced. The infected debris left in the field might serve as a major source of infection, for causing epidemic throughout the season.

The results of present study was supported by Vanitha et al., (2009), found the disease incidence in plants ranged from 9 to 39 per cent whereas, the incidence in seeds ranged from 4 to 18 per cent in major tomato growing districts of Karnataka state. Deepaet al., (2003) confirmed the nine strains of $R$. Solanacearum belongs to Races 1 and 3 isolated from the bacterial wilt affected plants of brinjal, chilli and tomato in three different agro climatic zones of Kerala. Chandrashekara et al., (2012) collected 57 isolates of $R$. solanacearum causing wilt on different host plants from different agro climatic zones of India. Narasimhamurthy and Srinivasa (2012) concluded that 85 isolates from different agro-climatic regions of Karnataka and other parts of India belong to biovar III.

Brinjal plants showing typical symptoms of bacterial wilt caused by Ralstonia solanacearum collected from different agroclimatic zones of the state were used for the isolation of the causal organism (Plate 2).

The bacteria was isolated from the different samples collected and designated as shown in Table 2. All the isolates showed the development of well separated irregularly shaped, fluidal, dull white colonies with slight red center typical of virulent $R$. solanacearum colonies (Plate 3).All the isolates collected showed gram negative reaction (Plate 4).

In conclusion the bacterial wilt of brinjal is a major disease occurring in almost all the major brinjal growing areas though the incidence varied. The isolates isolated all exhibited the typical characteristics of the $R$. solanacearum. 


\section{Acknowledgment}

The authors would like to acknowledge the Department of Plant Pathology, College of Horticulture, Bengaluru, UHS, Bagalkot for smooth conduct of experiment.

\section{References}

Anonymous, 2014, National Horticulture Board data base, National Horticulture Board, Ministry of Agriculture, Government of India, Gurgaon, pp 127135.

Chandrashekara, K. N., Reddy, M. K., Prasannakumar, Deepa, M., Akellavani and Khan, A. N. A., 2012, Prevalence of races and biotypes of Ralstonia solanacearumin India. J. Pl. Prot.Res., 52(1): 53-58.

Deepa, J., Girija, D., Sally, K., Mathew, P. N., Nazeem, T. D., Babu and Sukumaravarma, A., 2003, Detection of Ralstonia solanacearumrace 3 causing bacterial wilt of solanaceous vegetables in Kerala using random amplified polymorphic DNA (RAPD) analysis. $J$. Tropical Agri., 41:33-37.

Hayward, A. C., 1991, Biology and epidemiology of bacterial wilt caused by
Pseudomonas solanacearum. Ann. Rev. Phytopathol., 29: 65-87.

Kelman, A., 1954, The relationship of pathogenicity of Pseudomonas solanacearum to colony appearance in tetrazolium medium. Phytopathol.,44: 693-695.

Narasimhamurthy, K. and Srinivas, C., 2012, In vitro screening of bio antagonistic agents and plant extracts to control bacterial wilt (Ralstonia solanacearum) of tomato (Lycopersicon esculentum). J. Agri. Tech., 8(3): 999-1015.

Rao, M. V. B., Sohi, M. S. and Vijay, O. P., 1976, Reaction of some varieties of brinjal (Solanum melongena L.) to Pseudomonas solanacearum. Veg. Sci., 3(5): 61-64.

Sabita, J. N., Boruah, B. M. and Rachid, H. A., 2000, Yield potentiality of some brinjal cultivars in severely bacterial wilt infected condition. Veg. Sci., 27: 76-77.

Vanitha, S. C., Niranjana, S. R., Mortensen, C. N. and Umesha, S., 2009, Bacterial wilt of tomato in Karnataka and its management by Pseudomonas fluorescens. 54(5): 685-695.

\section{How to cite this article:}

Santosh Bangi, V. Devappa and Sangeetha, C. G. 2020. Survey and Collection of Bacterial Wilt (Ralstonia solanacearum) Isolates from Different Agro Climatic Zones of Karnataka. Int.J.Curr.Microbiol.App.Sci. 9(07): 3029-3032. doi: https://doi.org/10.20546/ijcmas.2020.907.356 